\title{
Mantle xenocrysts from the Masontown, Pennsylvania (USA) kimberlite: An ordinary mantle with Si-enriched spinels
}

\author{
Daniel J. Schulze ${ }^{1}$ and B. Carter Hearn, $\mathbf{J r}^{2}$ \\ ${ }^{1}$ Department of Geology, University of Toronto, Erindale College, Mississauga, Ontario, Canada \\ ${ }^{2}$ US Geol. Survey, Reston, VA, USA, and Smithsonian Natl. Mus. Natural History, Washington, DC, USA
}

\begin{abstract}
A kimberlite dike near Masontown in southwestern Pennsylvania, U.S.A. has intruded Paleozoic sedimentary rocks overlying Proterozoic (Grenville) basement. It contains abundant mantle-derived xenocrysts and dunites/olivine megacrysts and rare garnet lherzolites. Most garnet xenocrysts are derived from lherzolites (75\%) with $\mathrm{Cr} 2 \mathrm{O} 3$ in the range 2$10 \mathrm{wt} \%, \mathrm{TiO} 2=0.1-1.0, \mathrm{mg} \#=0.79-0.85$. The remainder belong to the Cr-poor megacryst suite $(\mathrm{Cr} 2 \mathrm{O} 3=0.5-3.6 \mathrm{wt} \%, \mathrm{TiO} 2=0.3-1.0, \mathrm{mg} \#=$ 0.76-0.84). Cr-diopside xenocrysts, primarily garnet lherzolite-derived, belong to two populations. One group equilibrated near the near the diamond-graphite transition approximately along a typical steady-state geothermal gradient (850-1030 degrees C, 130-150 km). Most cluster significantly above such a gradient at approximately 1320-1350 degrees C, 168-173 $\mathrm{km})$. Megacrysts and macrocrysts of ilmenite are strongly zoned with cores of diverse composition (e.g., $\mathrm{MgO}$ from 5 to $13 \mathrm{wt} \%, \mathrm{Cr} 2 \mathrm{O} 3$ from 0 to $1.8 \mathrm{wt} \%)$ to rims with a restricted compositional range (most in the range $\mathrm{MgO} 10-14 \mathrm{wt} \%$, Cr2O3 1.2-3.8 wt $\%$ and primarily lower Fe2O3 than cores). Cr-spinel xenocrysts have moderate Cr2O3 contents (25-53 wt\%) relative to many kimberlite occurrences, significantly lower than chromites associated with diamonds.
\end{abstract}

An unusual feature of this mantle suite is that most Cr-spinel xenocrysts have unusually high silica contents. Of $87 \mathrm{Cr}$-spinel xenocrysts (0.5 - $1 \mathrm{~mm}), 76$ have $\mathrm{SiO} 2$ values in the range 0.20 to $0.59 \mathrm{wt} \%$. Such values were obtained using electron microprobes at both $U$ of Toronto and U.S.G.S. A few dunites/olivine megacrysts host high silica Cr-spinels $(\mathrm{SiO} 2=0.23$ to 0.40 wt $\%$ ) but the olivine compositions are not unusual (e.g., Fo 90 - 92, $\mathrm{NiO}=0.31$ - 0.37). Equilibration temperatures (860 - 1100 degrees C) of these spinels (ol-sp Mg-Fe exchange in dunites or assuming coexistence of xenocrysts with Fo 91 olivine) are not particularly high for mantle materials and thus there is no reason to expect that the high silica content is due to formation at anomalously great depths. Instead, they are consistent with the steady-state garnet lherzolitederived pyroxene P-T conditions. Similar highsilica Cr-spinels are virtually absent $(n=2)$ from our data base for chromite xenocrysts from kimberlites in southern Africa $(\mathrm{n}=1369$ from 18 kimberlites), though there are some similar occurrences among kimberlites in North America. High SiO2 (> 0.20 wt\%) Cr-spinel xenocrysts occur at Lake Ellen, Michigan (39 of 63 grains) and at Sloan (9 of 36) and Kelsey Lake (17 of 75), but not at the neighbouring Schaffer kimberlite, in the Colorado-Wyoming kimberlite district.

Most of the characteristics of the subGrenville mantle in this location appear similar to those of typical sub-cratonic mantle. It is dominated by garnet lherzolites and has been influenced by proto-kimberlite magmas that have heated and metasomatized the mantle, and produced members of the Cr-poor megacryst suite. The compositions of the "indicator minerals" are consistent with the apparent absence of diamonds (none reported) as is the off-craton location. The existence of high-silica chromites is not understood, as there is no suggestion of other unusual geochemical conditions or particularly anomalous equilibration conditions. The elevated Si-in-spinel values suggest a silica activity greater than that expected in a peridotite, however, which might be explained by equilibration in a pyroxenitic association, though such xenoliths have not been found. 